\title{
ANALISIS PENDAPATAN USAHATANI BAWANG DAUN DI DESA MANEMBO KECAMATAN PASSI TIMUR KABUPATEN BOLAANG MONGONDOW
}

\author{
Christofel Denis Ratu \\ Rine Kaunang \\ Tommy Fredy Lolowang
}

\begin{tabular}{ll}
\hline Naskah diterima melalui E-mail Jurnal Ilmiah agrisosioekonomi@ unsrat.ac.id & $:$ Kamis, 30 Januari 2020 \\
Disetujui diterbitkan & $:$ Jumat, 29 Mei 2020 \\
\hline
\end{tabular}

\begin{abstract}
This study aims to analyze the income of leek farming in Manembo Village, Passi Timur Sub-district, Bolaang Mongondow Regency. This research lasted for 2 months, from November to December 2019. Sampling in this study was carried out by simple random sampling method with a number of respondents were 25 leek farmers. Primary data were collected through direct interviews using a list of questions (questionnaires) that have been prepared. Secondary data were obtained from the literature related to this research and related institutions. Data analysis used in this research is to use quantitative descriptive analysis and expenditure (production costs) to analyze the income of leek farming. The results showed that the income of onion farming in Manembo Village, East Passi District, Bolaang Mongondow District per farmer on average was IDR. 2,688,800.- ${ }^{*}$ eprm*
\end{abstract}

Keywords : leek, farming, income analysis

\begin{abstract}
ABSTRAK
Penelitian ini bertujuan untuk menganalisis pendapatan usahatani bawang daun di Desa Manembo Kecamatan Passi Timur Kabupaten Bolaang Mongondow. Penelitian ini berlangsung selama 2 bulan yaitu dari bulan November sampai Desember 2019. Pengambilan sampel dalam penelitian ini dilakukan dengan metode pengambilan sampel acak sederhana (simple random sampling) dengan jumlah responden sebanyak 25 petani bawang daun. Data primer dikumpulkan melalui wawancara langsung dengan menggunakan daftar pertanyaan (kuesioner) yang telah disiapkan. Data sekunder diperoleh dari literatur-literatur yang terkait dengan penelitian ini dan instansi terkait. Analis data yang digunakan dalam penelitian ini yaitu dengan menggunakan analisis deskriptif kuantitatif dan pengeluaran (biaya produksi) untuk menganalisis pendapatan usahatani bawang daun. Hasil penelitian menunjuklan bahwa pendapatan usahatani bawang daun di Desa Manembo Kecamatan Passi Timur Kabupaten Bolaang Mongondow per petani rata-rata adalah Rp.2.688.800.- ${ }^{*}$ eprm*
\end{abstract}

Kata kunci : bawang daun, usahatani, analisis pendapatan 


\section{PENDAHULUAN}

\section{Latar Belakang}

Pertanian merupakan salah satu sektor yang memiliki peranan penting dalam perekonomian Indonesia terutama dalam pembentukan Produk Domestik Bruto (PDB) (Handyoko, 2011). Hortikultura sebagai salah satu subsektor pertanian, menempati urutan kedua setelah tanaman pangan dalam struktur pembentukan PDB sektor pertanian. Subsektor hortikultura memperlihatkan kecenderungan yang terus meningkat terhadap pembentukan PDB terutama produksi sayuran.

Tanaman sayuran adalah jenis komoditi yang memiliki nilai ekonomi tinggi dan berperan penting dalam pemenuhan berbagai kebutuhan keluarga petani. Hal ini dapat ditunjukkan dengan beberapa fenomena diantaranya adalah tanaman sayur-sayuran berumur relatif pendek sehingga cepat dihasilkan, dapat diusahakan dengan mudah, mengunakan teknologi sederhana, dan hasil produksi sayur-sayuran cepat terserap pasar karena merupakan salah satu komponen susunan menu keluarga yang tidak dapat ditinggalkan.

Pendapatan yang cukup besar dalam ekonomi pertanian tidak bermakna bila harus di dapatkan dengan menggunakan pencurahan biaya produksi dengan jumlah besar. Namun sebenarnya pilihan-pilihan yang paling penting dilakukan petani adalah bagaimana memperoleh rasio yang cukup lebar antara pendapatan yang diperoleh dari kegiatan usahatani bila di bandingkan dengan total biaya produksi yang telah dikeluarkan. Semakin besar rasio yang diperoleh maka semakin tepat pilihan-pilhan penggunaan sumber daya yang di lakukan untuk kegiatan usahatani (Soekartawi, 1985).

Potensi ekonomi beberapa tanaman hortikultura sangat besar, karena harganya yang tinggi dan juga waktu yang dibutuhkan untuk produksinya singkat. Beberapa jenis tanaman sayuran dapat di tanam beberapa kali dalam setahun, terutama di daerah tropis, yang musim tanam tidak dibatasi oleh musim dingin sebagaimana yang terjadi pada daerah beriklim sedang (Lakitan, 2003).
Pada saat terjadi krisis ekonomi di Indonesia, komoditas hortikultura yang meliputi tanaman sayuran, buah-buahan, dan tanaman hias merupakan salah satu pemicu pertumbuhan ekonomi baru pada sektor pertanian. Bahkan beberapa produk komoditas sayuran Indonesia telah menjadi mata dagang ekspor dan sumber devisa negara. Oleh karena itu, produksi, produktivitas, dan kualitas sayuran nasional perlu ditingkatkan terutama untuk jenis sayuran potensial yang selama ini belum mendapat perhatian. Salah satu jenis komoditas sayuran potensial dan layak dikembangkan secara intensif dalam skala agribisnis adalah bawang daun (Allium fistulosum L.). Tanaman ini diduga berasal dari kawasan Asia Tenggara, kemudian meluas ditanam di berbagai daerah (Negara) yang beriklim tropis maupun subtropis (Meltin, 2009).

Salah satu komoditas sayuran yang potensial untuk dikembangkan adalah bawang daun. Bawang daun merupakan jenis sayuran dari kelompok bawang yang banyak digunakan sebagai penyedap dalam masakan. Selain sebagai bahan penyedap dalam masakan, bawang daun juga mengandung unsur-unsur aktif yang memiliki daya bunuh bakteri (sebagai antibiotik) serta dapat merangsang pertumbuhan sel tubuh. Bawang daun adalah salah satu sumber mata pencaharian pokok dan menjadi sumber pendapatan sebagian besar masyarakat dan petani di Desa Manembo di samping kegiatan lainnya. Pendapatan dan keuntungan dihitung dari besarnya penerimaan dikurangi dengan seluruh biaya-biaya yang digunakan dalam pengolahan bawang daun mulai dari alat dan bahan-bahan seperti cangkul, bibit, pupuk, transportasi, tenaga kerja dan biaya lainnya yang dapat mempengaruhi besarnya keuntungan yang diperoleh petani. Namun petani di Desa Manembo selama ini belum pernah melakukan analisis tentang berapa besar pendapatan usahatani bawang daun yang diterima oleh petani. Walaupun bagi petani setempat tetap dilakukan karena usahatani ini merupakan mata pencaharian masyarakat. Oleh karena itu aspek efisiensi harus mendapat perhatian yang serius, sehingga biaya-biaya yang dikeluarkan selama proses produksi dapat tertutupi dengan pendapatan dan keuntungan yang diperoleh setelah panen. 


\section{Rumusan Masalah}

Berdasarkan uraian latar belakang di atas, maka yang menjadi permasalahan ini adalah bagaimana pendapatan usahatani bawang daun di Desa Manembo Kecamatan Passi Timur Kabupaten Bolaang Mongondow?

\section{Tujuan Penelitian}

Penelitian ini bertujuan untuk menganalisis pendapatan usahatani bawang daun di Desa Manembo Kecamatan Passi Timur Kabupaten Bolaang Mongondow.

\section{Manfaat Penelitian}

Hasil penelitian ini diharapkan dapat memberikan manfaat kepada Desa Manembo sebagai bahan masukan bagi petani dalam mengembangkan usahatani bawang daun, bahan informasi bagi pemerintah daerah dalam mengambil kebijakan pengembangan usahatani bawang daun, dan sebagai bahan referensi untuk penelitian lanjutan.

\section{METODE PENELITIAN}

\section{Waktu dan Tempat Penelitian}

Penelitian ini berlangsung selama 2 bulan yaitu dari bulan November sampai Desember 2019, di Desa Manembo Kecamatan Passi Timur Kabupaten Bolaang Mongondow. Mulai dari persiapan sampai pada penyusunan laporan.

\section{Pengambilan Data}

Pengumpulan data menggunakan metode penelitian dengan pendekatan secara individual melalui kegiatan observasi langsung ke lapangan untuk mengidentifikasi petani yang mengusahakan Bawang Daun. Pengambilan data dilakukan dengan dua jenis data, yaitu data primer dan data sekunder. Data primer diperoleh dari hasil wawancara langsung dengan responden serta menggunakan daftar kuesioner. Sedangkan untuk data sekunder diperoleh dari literatur-literatur yang terkait dengan penelitian ini dan instansi terkait di Desa Manembo Kecamatan Passi Timur Kabupaten Bolaang Mongondow.

\section{Pengambilan Sampel}

Pengambilan sampel dalam penelitian ini dilakukan dengan metode sampel acak sederhana (simple random sampling). Data dikumpulkan melalui wawancara dengan menggunakan daftar pertanyaan (kuesioner) yang telah disiapkan dan yang menjadi responden yaitu Petani Bawang Daun yang berada di Desa Manembo Kecamatan Passi Timur Kabupaten Bolaang Mongondow dengan jumlah responden sebanyak 25 petani.

\section{Konsep Pengukuran Variabel}

Variabel yang digunakan dalam penelitian ini adalah sebagai berikut:

a. Produksi adalah keseluruhan hasil yang berasal dari usahatani Bawang Daun yang diperoleh dalam 1 kali panen dinyatakan dalam $\mathrm{kg} / \mathrm{ha}$.

b. Nilai produksi adalah jumlah produksi yang dihasilkan atau diperolehdengan harga yang berlaku dalam satu kali panen.

c. Luas lahan adalah lahan yang digarap untuk mengusahakan usahatani Bawang Daun dinyatakan dengan satuan hektar.

d. Tenaga kerja adalah tenaga kerja yang digunakan dalam kegiatan usahatani Bawang Daun baik berasal dari keluarga maupun diluar keluarga.

e. Biaya produksi usahatani adalah semua biaya yang dikeluarkan petanidalam proses usahatani Bawang Daun yang dinyatakan dalam (RP/tiap kalipanen). Terdiri biaya tetap

f. Pendapatan adalah total keseluruhan keuntungan dibagi dengan seluruh totalbiaya yang dikeluarkan. Dinyatakan dalam Rupiah (Rp).

g. Harga adalah suatu nilai tukar yang bisa disamakan dengan uang atau barang lain untuk manfaat yang diperoleh dari suatu barang atau jasa bagi seseorang pada waktu tertuntu.

h. Penerimaan adalah sejumlah uang yang diterima oleh perusahaan atas penjualan produk yang dihasilkan.

\section{Metode Analisis Data}

Analis data yang digunakan dalam penelitian ini yaitu dengan menggunakan analisis deskriptif kuantitatif dan pengeluaran (biaya produksi) untuk menganalisis pendapatan usahatani bawang daun di Desa Manembo sehingga dapat di hitung ratio penerimaan dan pendapatan. 


\section{Biaya}

Menurut Gilarso dalam Mugiono dkk (2014), biaya produksi merupakan penjumlahan dari dua komponen biaya yaitu biaya tetap (fixed cost) dan biaya variabel (variablecost). Gabungan biaya tetap dan biaya variabel disebut biaya total (total cost) yang secara umum dirumuskan sebagai berikut:

Keterangan:

$$
\mathrm{TC}=\mathrm{FC}+\mathrm{VC}
$$

$\mathrm{TC}=$ Biaya total (Total Cost)

$\mathrm{FC}=$ Biaya tetap (Fixed Cost)

$\mathrm{VC}=$ Biaya variabel $($ Variable cost $)$

Penerimaan Menurut Soekartawi (1995), yaitu penerimaan usaha adalah perkalian antara produksi yang diproduksi dengan harga jual, pernyataan ini ditulis sebagai berikut:

Keterangan:

$$
\mathrm{TR}=\mathrm{Y} . \mathrm{Py}
$$

$\mathrm{TR}=$ Total penerimaan (Total Revenue)

$\mathrm{Y}=$ Produksi yang diperoleh dalam usaha

Py $=$ Harga

Pendapatan usahatani bawang daun pendapatan dihitung dengan menggunakan konsep pendapatan usaha yaitu selisih antara penerimaan dan semua biaya.

Keterangan:

$$
\mathrm{Pd}=\mathrm{TR}-\mathrm{TC}
$$

$\mathrm{Pd}=$ Pendapatan

$\mathrm{TR}=$ Total Penerimaan $($ Total revenue $)$

$\mathrm{TC}=$ Total Biaya $($ Total Cost $)$

\section{HASIL DAN PEMBAHASAN}

\section{Gambaran Umum Lokasi Penelitian}

Desa Manembo terletak di Kecamatan Passi Timur, Kabupaten Bolang Mongondow, Provinsi Sulawesi Utara. Jarak dengan Ibukota/kota $70 \mathrm{~km}$. Wilayah ini merupakan wilayah dataran tinggi (pegunungan), dengan jumlah penduduk 1280 jiwa, yang sebagian besar penduduk bermata pencaharian sebagai petani.

Desa Menembo berada di Kecamatan Passi Timur yang merupakan salah satu kecamatan yang ada di Kabupaten Bolaang Mongondow, secara geografis desa ini berada di daerah pegunungan, memiliki iklim musim (muson). Pada bulan Mei sampai Oktober bertiup angin barat yang kering dan akan menimbulkan musim kemarau, suhu rata-rata perbulan di desa ini minimum antara $17-23^{\circ} \mathrm{C}$ dan maksimum antara $25-31{ }^{\circ} \mathrm{C}$ dengan curah hujan pertahun rata-rata $2.275 \mathrm{~mm}$ dan perbulan rata-rata $1.899 \mathrm{~mm}$. kecepatan angin minimum 2 knot/jam dan maksimum $10 \mathrm{knot} / \mathrm{jam}$. berikut :

Batas administratif Desa Manembo sebagai

1. Sebelah Timur berbatasan dengan Desa Pangian.

2. Sebelah Barat berbatasan dengan Desa Sinsingon Barat.

3. Sebelah Selatan berbatasan dengan Desa Poopo.

4. Sebelah Utara berbatasan dengan Desa Tuduaog.

\section{Karakteristik Responden}

Jumlah penduduk yang ada di desa Manembo sebanyak 655 jiwa laki-laki dan 625 jiwa perempuan, total 1280 jiwa dengan jumlah kepala keluarga 348. Penduduk Desa Manembo sebagian besar bermata pencaharian sebagai petani.

Tingkat perekonomian masyarakat Desa Manembo termasuk golongan ekonomi sedang karena sebagian besar masyarakat berpotensi sebagai petani. Selain itu SDM dari masyarakat yang masih rendah menyebabkan tingkat keberhasilan usaha-usaha dari masyarakat masih relatif kategori sedang, akibatnya peningkatan ekonomi juga relatif sedang.

\section{Karakteristik Responden Menurut Tingkat Umur}

Umur petani merupakan salah satu faktor yang berkaitan erat dengan kemampuan kerja petani dalam melakukan kegiatan usahatani. Semakin tua umur petani, maka kemampuan kerja akan cendrung menurun dan dapat berpengaruh terhadap produksi dan pendapatan yang diperoleh. Hal ini karena pekerjaan sebagai petani lebih banyak mengandalkan tenaga fisik. Dari 25 petani responden menunjukkan bahwa kisaran umur petani adalah 30-65 tahun. Seperti terlihat pada Tabel 1.

\begin{tabular}{cccr}
\multicolumn{4}{l}{ Tabel 1. Jumlah Responden Menurut Golongan Umur } \\
\hline No & Umur (Tahun) & Jumlah (Jiwa) & Persentase (\%) \\
\hline 1. & $30-45$ & 12 & 48 \\
2. & $46-55$ & 7 & 28 \\
3. & $56-65$ & 6 & 24 \\
\hline \multicolumn{4}{l}{ Sumber : Diolah dari Data Primer, 2019 }
\end{tabular}


Tabel 1 menunjukkan petani berusia 30 sampai 45 tahun memiliki persentase terbesar yaitu $48 \%$ dengan jumlah jiwa terbanyak yaitu 12 petani, untuk usia 46 sampai 55 tahun memiliki persentase sebesar $28 \%$ dengan jumlah jiwa 7 petani, dan untuk usia 56 sampai 65 tahun memiliki persentase terkecil yaitu $24 \%$ dengan jumlah jiwa sebanyak 6 petani.

\section{Karakteristik Responden Menurut Tingkat Pendidikan}

Pendidikan merupakan faktor yang sangat penting bagi peningkatan SDM. Adanya pendidikan yang memadai dapat meningkatkan kecakapan petani dalam mengusahakan usahatani sehingga dapat menguntungkan taraf hidup para petani. Pendidikan berpengaruh juga terhadap kemampuan berpikir dan beradaptasi dengan lingkungan. Tingkat pendidikan petani Bawang Daun di Desa Manembo dapat dilihat pada Tabel 2.

\begin{tabular}{cccr}
\multicolumn{5}{c}{ Tabel 2. Tingkat Pendidikan Formal Responden } \\
\hline No & Pendidikan Terakhir & Jumlah (Jiwa) & Persentase (\%) \\
\hline 1. & SD & 14 & 56 \\
2. & SMP & 7 & 28 \\
3. & SMA & 4 & 16 \\
\hline & Jumlah & 25 & 100 \\
\hline
\end{tabular}

Sumber : Diolah dari Data Primer, 2019

Tabel 2 menunjukkan bahwa pendidikan petani di Desa Manembo berjenjang dari Sekolah Dasar (SD), Sekolah Menengah Pertama (SMP), dan Sekolah Menengah Atas (SMA). Persentase terbesar adalah berpendidikan SD, yaitu 14 jiwa petani dengan persentase 56\%. Petani yang berpendidikan SMP sebanyak 7 jiwa petani dengan persentase $28 \%$, dan petani yang berpendidikan pada tingkat SMA yaitu 4 jiwa petani dengan persentase $16 \%$.

\section{Jumlah Tanggungan Keluarga}

Salah satu faktor yang berpengaruh dalam mengembangkan usahatani adalah keluarga. Dengan menggunakan tenaga kerja keluarga akan mewarisi tradisi wirausahawan yang dengan mudah mengusahakan usahatani sehingga dapat tercapai proses keberhasilan dibandingkan dengan keluarga yang tidak mewarisi hal tersebut. Klasifikasi jumlah tanggungan keluarga petani Bawang Daun di Desa Manembo seperti terlihat pada Tabel 3.
Tabel 3. Jumlah Tanggungan dan Persentase Keluarga

\begin{tabular}{cccr}
\multicolumn{2}{c}{ Responden } & & \\
\hline \multirow{2}{*}{ No } & $\begin{array}{c}\text { Jumlah Tanggungan } \\
\text { Keluarga }\end{array}$ & $\begin{array}{c}\text { Jumlah } \\
(\text { Jiwa })\end{array}$ & $\begin{array}{c}\text { Persentase } \\
(\%)\end{array}$ \\
\hline 1. & 2 & 6 & 24 \\
2. & $3-4$ & 16 & 64 \\
3. & 5 & 3 & 12 \\
\hline & Jumlah & 25 & 100 \\
\hline
\end{tabular}

Sumber : Diolah dari Data Primer, 2019

Tabel 6 menunjukkan bahwa jumlah anggota keluarga responden Desa Manembo yang memliliki jumlah anggota keluarga paling banyak 3 sampai 4 tanggungan dengan jumlah jiwa sebanyak 16 dan persentase sebesar $64 \%$, dan jumlah angota keluarga responden yang memiliki kelompok anggota terendah sebanyak 5 tanggungan yaitu jumlah jiwa sebanyak 3 orang dengan persentase $12 \%$. Hal ini menunjukkan bahwa semakin besar jumlah anggota keluarga maka semakin besar pula tingkat konsumsi keluarga dan semakin besar pula pendapatan yang digunakan untuk konsumsi keluarga.

\section{Karakteristik Usahatani Bawang Daun di Desa Manembo}

\section{Luas Lahan}

Lahan merupakan faktor produksi yang penting dalam setiap usahatani, karena lahan merupakan tempat atau media tanam komoditi yang akan di budidayakan oleh petani.

\begin{tabular}{cccr}
\multicolumn{5}{c}{ Tabel 4. Luas Lahan Usahatani di Desa Manebo } \\
\hline \multirow{2}{*}{ No } & $\begin{array}{c}\text { Luas Lahan } \\
\text { (Ha) }\end{array}$ & $\begin{array}{c}\text { Jumlah Petani } \\
\text { (orang) }\end{array}$ & Persentase (\%) \\
\hline 1. & $0,35-0,50$ & 12 & 48 \\
2. & $0,51-1$ & 9 & 36 \\
3. & $2-3$ & 4 & 16 \\
\hline & Jumlah & 25 & 100 \\
\hline
\end{tabular}

Sumber : Diolah dari Data Primer, 2019

Tabel 4 menunjukkan bahwa jumlah petani terbanyak dalam mengelolah lahan untuk usahatani bawang daun pada luas lahan 0,35$0,50 \mathrm{Ha}$, yaitu sebanyak 12 orang atau sekitar $48 \%$. Luas lahan 0,51-1 Ha terdapat petani sebanyak 9 orang atau sekitar 36\%. Sedangkan yang paling sedikit pada luas lahan 2-3 Ha, yaitu 4 orang atau sekitar $16 \%$. Untuk kepemilikan lahan usahatani bawang daun adalah milik sendiri dari setiap masing-masing petani. 


\section{Status Kepemilikan Lahan}

Status kepemilikan lahan sangat berpengaruh terhadap tingkat pendapatan petani, karena status kepemilikan lahan juga mempengaruhi biaya yang akan di keluarkan petani. Kepemilikan lahan petani bawang daun di Desa Manembo adalah milik sendiri dengan persentase $100 \%$. Para petani menggarap lahannya dengan membudidayakan berbagai jenis macam tanaman seperti bawang daun, kentang, wortel, goraka, tomat dan sebagainya.

\section{Biaya Produksi Usahatani Bawang Daun}

Biaya produksi adalah biaya yang dikeluarkan petani dalam satu kali proses produksi, meliputi biaya tetap dalam usahatani bawang daun yaitu pajak tanah serta penyusutan alat sedangkan biaya tidak tetap yaitu biaya bibit, pupuk, pestisida dan tenaga kerja.

Tabel 5. Biaya Rata-Rata Variabel Usahatani Bawang

\begin{tabular}{llc}
\multicolumn{3}{c}{ Daun } \\
\hline No & Biaya Variabel & Rata-Rata \\
\hline 1. & Bibit & 8.900 .00 \\
2. & Pengolahan & 72.000 .00 \\
3. & Lahan & 72.000 .00 \\
4. & Penanaman & 44.800 .00 \\
5. & Penyemprotan & 99.200 .00 \\
6. & Penyiangan & 176.000 .00 \\
7. & Pemupukan & 240.000 .00 \\
8. & Penimbunan & 173.333 .3 \\
9. & Pupuk Pestisida & 5.38000 \\
\hline & Jumlah & 73.561 .333 \\
\hline
\end{tabular}

Sumber : Diolah dari Lampiran 3

Table 5 menunjukkan rata-rata biaya variable biaya usahatani bawang daun adalah Rp 73.561.333,00 petani bawang daun selama satu kali proses produksi mengeluarkan biaya untuk bibit sebesar 8.900,00, biaya pupuk sebesar 173.333,3 dan pestisida 5.380,00.

\section{Pajak}

\section{Biaya Tetap}

Pajak adalah pungutan wajib yang dibayar rakyat untuk negara dan akan digunakan untuk kepentingan pemerintah dan masyarakat umum. Pajak yaitu biaya tanah yang di bayar per tahun. Dalam hal ini biaya produksi di hitung per satu musim tanam. Menurut hasil penelitian biaya pajak di tanggung oleh pemilik lahan sendiri dan biaya yang di keluarkan petani Rp 64.000,00 per 1 hektar.

\section{Peralatan}

Dalam pengelolaan lahan usahatani bawang daun, peralatan yang diperlukan yakni cangkul, sekop, dan hand sprayer. Seluruh petani yang ada di Desa Manembo memiliki dan menggunakan alat tersebut. Setiap tenaga kerja yang di sewa dalam usahatani bawang daun menggunakan alatnya masing-masing.

\section{Biaya Tidak Tetap}

\section{Bibit}

Bibit yang di dapat adalah dari tanaman hasil perbanyakan melalui peranakkan yang siap untuk ditanam. Bibit yang dipersiapkan untuk tanaman biasanya telah melalui proses seleksi sehingga diharapkan dapat mencapai proses tumbuh yang baik. Bibit yang digunakan petani di Desa Manembo umumnya bibit yang berasal dari peranakkan yang berasal dari usahatani bawang daun sebelumnya. Struktur tumbuh tanaman bawang daun terdiri atas, akar, batang semu, dan daun. Disamping itu, pada stadium reproduktif dapat menghasilkan bunga dan biji. System perakarannya termasuk akar serabut yang terpencar kesemua arah pada kedalaman antara $15-30 \mathrm{~cm}$, bagian batang semu yang tertimbun tanah, umumnya berwarna putih bersih sedangkan batang semu yang berada dipermukaan tanah berwarna hijau keputihputihan. Sifat hidup tanaman ini berumpun, yakni membentuk anak-anakkan yang baru.

\section{Tenaga Kerja}

Petani bawang daun di desa Manembo menggunkan tenaga kerja pada tahap pengolahan lahan, penanaman, penyemprotan, penyiangan, pemupukan, dan penimbunan dengan waktu kerja 6 jam, mulai dari pukul 07.00 am sampai dengan pukul $13.00 \mathrm{pm}$. Upah tenaga kerja yang berlaku di desa ini yaitu $\mathrm{Rp} 80.000$,- dan masyarakat Manembo juga menggunakan tenaga kerja Mapalus yang berjumlah 10 orang laki-laki.

3. Mapalus

Mapalus adalah suatu sistem atau teknik kerjasama untuk kepentingan bersama dalam budaya suku Minahasa. Secara fundamental, Mapalus adalah suatu bentuk gotong royong tradisional yang memiliki perbedaan dengan bentuk-bentuk gotong royong modern, misalnya perkumpulan atau asosiasi usaha. 


\section{Pengolahan lahan}

Petani bawang daun di Desa Manembo melakukan pengolahan lahan atau pembedengan sebelum penanaman. Upah tenaga kerja per orang Rp 80.000,- tetapi di Desa Manembo menggunakan tenaga kerja Mapalus.

5. Penanaman

Pada tahan penanaman ini dilakukan setelah pengolahan lahan biasanya tenaga kerja yang di pakai pada tahap penanaman sekitar 10-20 orang per hektar, di Desa Manembo melakukan tenaga kerja Mapalus.

6. Penyemprotan

Penyemprotan merupakan salah satu faktor penting dalam melakukan produksi bawang daun, peyemprotan saat tanaman bawang daun berumur 15 hari atau 2 minggu setelah tanam. Penyemprotan dilakukan 3 kali dalam satu kali panen. Tenaga kerja yang di pakai pada tahap penyemprotan petani itu sendiri atau pemilik lahan. Alat yang di gunakan saat penyemprotan menggunakan alat Tangki.

7. Penyiangan

Untuk penyiangan dilakukan pembersian rumput, yang menjadi pesaing utama tanaman bawang daun untuk memperoleh cahaya matahari dan unsur-unsur tanah. Penyiangan dilakukan dengan cara manual yaitu dengan mencabut atau di gali dengan menggunakan tangan. Pada saat penyiangan petani biasanya mencabut dan membuang tanaman bawang daun yang terkena penyakit atau hama.

Pada penanaman bawang daun penyiangan dilakukan 1 sampai 2 kali dalam satu kali panen. Upah tenaga kerja pada tahap ini Rp 80.000,- pada saat penyiangan petani hanya memerlukan 3 tenaga kerja, 1 tenaga kerja yang di gaji dan 2 tenaga kerja pemilik lahan untuk $0.50 \mathrm{Ha}$.

\section{Pemupukan}

Pemupukan bawang daun dilakukan 3 tahap. Tahap 1 dilakukan pada saat tanaman berumur 15 HST. Pemupukan ke 2 dilakukan 30 HST. Sedangkan pemupukan ke 3 dilakukan pada saat 2 minggu sebelum petani akan menjual bawang daun tersebut. Upah tenaga kerja yaitu Rp 80.000,-

\section{Penimbunan}

Pada tahap penimbunan ini dilakukan pada saat bawang daun berumur 40-50 setelah tanam. Upah tenaga kerja Rp 80.000,- tenaga kerja yang di pakai sekitar 2 orang.

\section{Pupuk}

Pupuk adalah material yang ditambahkan pada media tanam atau tanaman untuk mencukupi kebutuhan hara yang diperlukan tanaman sehingga mampu berproduksi dengan baik. Pemupukan adalah proses yang dilakukan oleh petani dengan pemberian unsur hara baik secara organik maupun kimia. Tujuannya adalah meningkatkan unsur hara pada lahan dan juga tanaman agar mempunyai produksi lebih baik. Jenis pupuk yang di gunakan oleh petani di Desa Manembo adalah seperti pupuk urea, pupuk kandang, pupuk SP, Ponska.

\section{Pestisida}

Pestisida merupakan obat-obatan yang digunakan untuk pembasmi hama dan penyakit pada tanaman. Serangan hama dan penyakit pada tanaman bawang daun dapat menimbulkan kerugian yang cukup banyak yaitu seperti menurunkan hasil panen, dapat menggagalkan panen, dan meningkatkan biaya produksi sehingga pendapatan usahatani rendah. Pestisida yang digunakan pada usahatani bawang daun adalah insektisida dan fungisida.

12. Panen

Panen dilakukan pada saat tanaman bawang daun sudah bermur 60 hari setelah tanam (HST). Pada tahap ini tidak ada biaya yang dikeluarkan petani karena seluruh biaya pemanenan akan ditanggung oleh pedagang pengumpul.

\section{Jumlah Produksi}

Produksi merupakan suatu kegiatan untuk meningkatkan manfaat dengan cara mengkombinsikan faktor-faktor produksi tanah, tenaga kerja dan modal.

Volume produksi merupakan faktor penentu besarnya pendapatan yang diterima oleh Petani Bawang Daun itu sendiri. Semakin besar volume produksi yang dihasilkan, maka akan semakin tinggi pula pendapatan para petani Bawang Daun di Desa Manembo.

\begin{tabular}{cccc}
\multicolumn{6}{c}{ Tabel 6. Volume Produksi Usahatani Bawang Daun } \\
\hline No & Jumlah Produksi & Jumlah Petani & Persentase (\%) \\
\hline 1. & $4.000-7.000$ & 15 & 60 \\
2. & $8.000-14.000$ & 6 & 24 \\
3. & $15.000-21.000$ & 4 & 16 \\
\hline \multicolumn{5}{l}{ Sumber : Diolah dari Data Primer, 2019 }
\end{tabular}


Tabel 6 menunjukkan banyaknya produksi bawang daun yang dihasilkan oleh petani bervariasi. Dimana jumlah produksi tertinggi yakni 21.000 atau $16 \%$. Sebagian besar petani bawang daun memproduksi 4.000-7.000, yakni sebanyak 15 petani atau $60 \%$, sedangkan jumlah produksi di antara 8.000- 14.000 sebanyak 6 petani atau $24 \%$.

\section{Harga Jual}

Harga merupakan persetujuan antara pembeli dan penjual dalam suatu produk tertentu, dalam hal ini peteni merupakan penjual komoditi Bawang Daun. Harga jual adalah variable paling utama dalam menentukan besarnya penerimaan suatu usahatani. Harga yang berlaku pada petani di Desa Manembo Rata-rata Rp. 500,-/Ikat.

\section{Penerimaan Usahatani Bawang Daun}

Penerimaan usahatani Bawang Daun adalah perkalian antara jumlah produksi Bawang Daun dan harga jual ditingkat petani. Oleh karena itu besarnya penerimaan usahatani Bawang Daun tergantung pada jumlah produksi dan harga tersebut.

\section{Pendapatan Usahatani Bawang Daun}

Pendapatan Usahatani Bawang Daun dapat diartikan sebagai biaya usahatani dan penerimaan usahatani, yaitu total penerimaan kotor di kurangi dengan total biaya produksi. Pendapatan usahatani bawang daun dapat dilihat pada Tabel 7 .

\begin{tabular}{llr} 
Tabel & $\begin{array}{l}\text { Rata-Rata Penerimaan, Biaya dan Pendapatan } \\
\text { Usahatani Bawang Daun di Desa } \\
\text { Musim Tanam }\end{array}$ & $\begin{array}{r}\text { Panembo per } \\
\text { Mumlah (Rp) }\end{array}$ \\
\hline No & Uraian & 4.450 .000 \\
\hline 1. & Penerimaan & 8.900 \\
2. & Biaya Produksi & 2.688 .800 \\
\hline 3. & Pendapatan & \\
\hline Sumber : Diolah dari Data Primer, 2019
\end{tabular}

Tabel 7 menunjukkan bahwa pendapatan usahatani bawang daun di Desa Manembo sebanyak Rp2.688.800. Pendapatan ini diperoleh dari penerimaan usahatani di kurang biaya produksi. Dari tabel- tabel di atas dapat dilihat bahwa bawang daun sangat berpengaruh terhadap kehidupan masyarakat di Desa Manembo. Karena dalam setiap stek bawang daun dapat membantu kehidupan masyarakat di Desa Manembo.

\section{KESIMPULAN DAN SARAN}

\section{Kesimpulan}

Berdasarkan hasil penelitian dan pembahasan, maka dapat disimpulkan bahwa Pendapatan Usahatani Bawang Daun di Desa Manembo Kecamatan Passi Timur Kabupaten Bolaang Mongondow per petani mendapat penghasilan rata-rata Rp.2.688.800,-

\section{Saran}

Berdasarkan beberapa temuan dalam penelitian ini, maka disarankan petani agar mempertahankan bahkan meningkatkan kinerja Usahatani Bawang Daun dengan meminimalisasi masalah yang dihadapi. Dan untuk peneliti selanjutnya agar meneliti tentang pemasaran Bawang Daun dan teknologi pascapanen untuk meningkatkan nilai jual komoditi bawang daun.

\section{DAFTAR PUSTAKA}

Handyoko A. 2011. Kontribusi Sektor Pertanian Terhadap PDB. Lembang: BBPP Lembang.

Lakitan, B. 2003. Hortikultura : Teori, Budidaya, dan Pasca Panen. Jakarta : PT. Raja Grafindo Persada.

Meltin. L. 2009. Budidaya Tanaman Bawang Daun (Allium Fistulosum L) di Kebun Benih Hortikultura (KBH) Tawangmangu. Universitas Sebelas Maret.

Mugiono, M., Marwanti, S., \& Awami, S. N. 2014. Analisis pendapatan usaha gula merah kelapa (studi kasus di Desa Medono Kecamatan Kaliwiro Kabupaten Wonosobo). Mediagro, 10(2).

Soekartawi dan Soeharjo A. 1985. Ilmu Usahatani dan Penelitian untuk Pengembangan Petani Kecil. Dillon JL, Hardaker, penerjemah; Jakarta: UIPress. Terjemahan dari: Farm Management Research for Small Development.

Soekartawi. 1995. Analisis Usahatani. Jakarta: UIPress. 